\title{
Visualisasi Sistem Informasi Pendaftaran Kadaster 3D \\ Studi Kasus: Rumah Susun Grudo, Surabaya
}

\author{
Isna Dwi Lestari dan Yanto Budisusanto \\ Departemen Teknik Geomatika, Fakultas Teknik Sipil dan Perencanaan, Institut Teknologi Sepuluh Nopember (ITS) \\ e-mail: yanto_b@geodesy.its.ac.id
}

\begin{abstract}
Abstrak-Tingkat kebutuhan akan ruang saat ini sangat tinggi hal ini disebabkan karena meningkatnya populasi manusia terutama di wilayah perkotaan. Oleh karena itu, pembangunan hunian secara horizontal menjadi kurang efisien. Untuk menjawab kebutuhan tersebut sejak tahun 1985 di Indonesia diperkenalkan konsep hunian vertikal dalam suatu UndangUndang tentang Rumah Susun. Untuk bangunan rumah susun, penerapan sistem kadaster dua dimensi (2D) kurang tepat, karena tidak dapat menggambarkan keadaan yang sebenarnya. Keterbatasan persil 2D ini mendorong lahirnya konsep kadaster tiga dimensi (3D) yang diharapkan dapat memberikan kepastian hukum dan informasi keakuratan data dalam menampilkan bangunan fisik. Oleh karena itu, pada penelitian ini dilakukan pembuatan sistem informasi pendaftaran kadaster 3D, dengan menggunakan studi kasus Rumah Susun Grudo, Kota Surabaya. Harapannya sistem ini nantinya mampu memberikan informasi terkait keruangan atau informasi spasial 3D dan dapat digunakan untuk melakukan pendaftaran kadaster 3D secara online. Sistem informasi ini menggunakan sistem basis data PostgreSQL dan untuk membuat tampilan website menggunakan bahasa pemrograman PHP dan HTML. Pembuatan model 3D bangunan rumah susun menggunakan perangkat lunak SketchUp Make yang kemudian di visualisasikan pada aplikasi sistem informasi. Hasil dari penelitian ini adalah sebuah Website Sistem Informasi Pendaftaran Kadaster 3D yang menyajikan informasi mengenai alur pendaftaran, syarat pendaftaran dan perpanjangan, formulir pendaftaran, dan visualisasi 3D.
\end{abstract}

Kata Kunci-Kadaster 3D, Pendaftaran, Rumah Susun, Sistem Informasi.

\section{PENDAHULUAN}

SURABAYA merupakan kota metropolitan dengan jumlah penduduk terbesar kedua setelah Jakarta. Sebagai kota metropolitan, Surabaya menjadi salah satu tujuan masyarakat yang ingin mencari pekerjaan. Hal ini mengakibatkan meningkatnya pertumbuhan penduduk di Surabaya.

Meningkatnya pertumbuhan penduduk yang semakin tinggi, menyebabkan kebutuhan akan lahan juga semakin meningkat. Oleh karena itu, dirasa pembangunan hunian secara horizontal menjadi kurang efisien. Terutama untuk wilayah perkotaan dengan luas tanah yang terbatas maka tidak dapat menjawab masalah tersebut.

Untuk menjawab masalah tersebut sejak tahun 1985 di Indonesia telah diperkenalkan konsep hunian vertikal dalam suatu Undang-Undang tentang Rumah Susun. Undang-Undang tersebut mengatur tentang tata cara pembangunan, pemilikan, penghunian dan pengelolaan rumah susun [1].

Bangunan rumah susun merupakan bangunan yang kompleks, sehingga penerapan sistem kadaster dua dimensi (2D) kurang tepat, karena tidak dapat menggambarkan keadaan yang sebenarnya. Keterbatasan persil 2D ini mendorong lahirnya konsep kadaster tiga dimensi (3D) yang diharapkan dapat memberikan kepastian hukum bagi kepemilikan atas bangunan rumah susun [1].

Kadaster adalah sistem informasi pertanahan berbasis persil yang berisi informasi terkini tentang segala kepentingan yang terkait dengan tanah, seperti hak atas tanah, batasan-batasan dan tanggung-jawab yang harus dipenuhi dalam pemilikan dan pengelolaan tanah [2]. Kadaster 3 dimensi merupakan sistem kadaster yang melakukan pendaftaran (register) dan memberikan gambaran pada hak / kewenangan (right) serta batasan-batasan (restriction), tidak hanya pada persil tanah, tetapi juga pada unit properti 3D [3].

Sebuah model 3D akan mampu memberikan kemudahan bagi pengguna untuk memilih posisi virtual dalam peta. Kadaster 3D akan dapat memberikan informasi keakuratan data yang lebih baik di dalam memahami dan menginterpretasi peta, serta kemampuan menampilkan bentuk yang lebih perspektif secara real dari bangunan fisik yang ada.

Pada pembuatan sistem informasi kadaster 3D, perlu dilakukan pembuatan model 3D dan basis datanya. Pembuatan model 3D dilakukan dengan menggunakan perangkat lunak SketchUp Make, sedangkan untuk pembuatan basis data dilakukan dengan menggunakan perangkat lunak PostgreSQL. Kedua komponen tersebut kemudian dihubungkan sehingga terbentuk sistem informasi kadaster 3D yang dapat memberikan informasi dari suatu ruangan.

Oleh karena hal tersebut di atas, maka penelitian ini dilakukan untuk membuat suatu sistem informasi pendaftaran kadaster 3D dengan menggunakan studi kasus Rumah Susun Grudo, Kota Surabaya. Harapannya sistem ini nantinya mampu memberikan informasi terkait keruangan atau informasi spasial 3D dan dapat digunakan untuk melakukan pendaftaran kadaster 3D secara online. Selain itu dengan adanya sistem ini dapat membantu Pemkot Surabaya dalam mengelola Rumah Susun Grudo. 


\section{METODOLOGI PENELITIAN}

\section{A. Lokasi Penelitian}

Lokasi yang akan dijadikan lokasi penelitian adalah Rumah Susun Grudo yang terletak di Kelurahan Dr. Soetomo, Kecamatan Tegalsari, Surabaya. Lokasi geografisnya terletak pada $7^{\circ} 16^{\prime} 38,5^{\prime \prime}-7^{\circ} 16^{\prime} 40,3^{\prime \prime}$ LS dan $112^{\circ} 44^{\prime} 11,1^{\prime \prime}-112^{\circ}$ 44'12,1" BT. Tampilan lokasi penelitian dapat dilihat pada Gambar 1 .

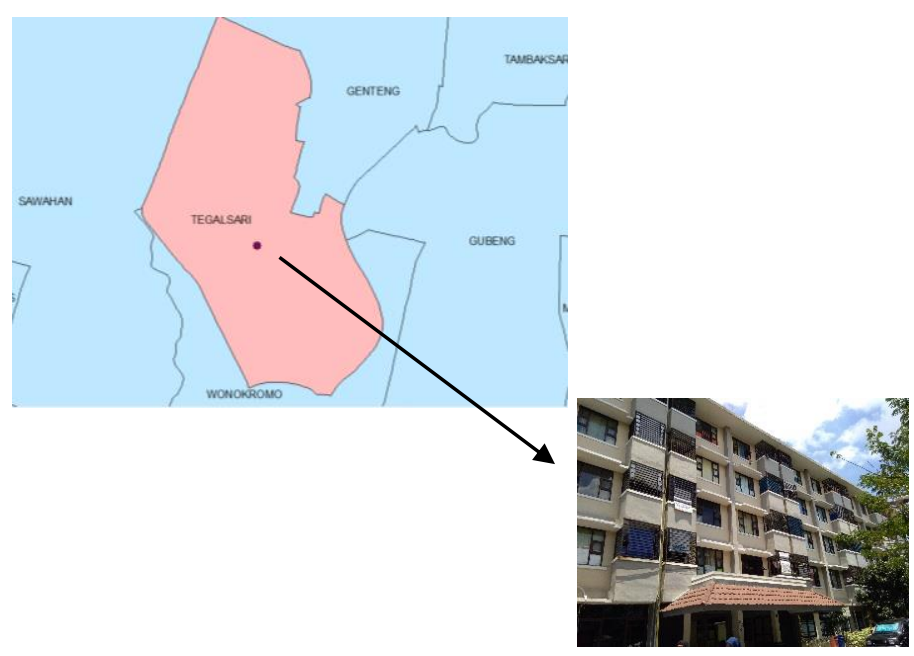

Gambar 1. Lokasi Penelitian

\section{B. Data dan Peralatan yang Digunakan}

Data-data yang digunakan dalam penelitian ini adalah sebagai berikut:

a. Data denah bangunan (kondisi lantai tiap bangunan) Rumah

Susun Grudo, Surabaya

b. Data penghuni tiap ruang Rumah Susun Grudo, Surabaya

c. Data biaya sewa rumah susun, biaya listrik dan air penghuni

Rumah Susun Grudo, Surabaya.

Peralatan yang digunakan dalam penelitian ini adalah sebagai berikut:

a. Perangkat keras (hardware)

Hardware yang digunakan terdiri dari :

- Laptop digunakan untuk memasukkan, menyimpan dan mengolah data

b. Perangkat lunak (software)

Software yang digunakan terdiri dari :

- SketchUp Make digunakan untuk proses pembuatan model 3D

- PostgreSQL digunakan untuk pembuatan basis data Rumah Susun Grudo

- XAMPP digunakan untuk menghubungkan server localhost

\section{Tahap Penelitian}

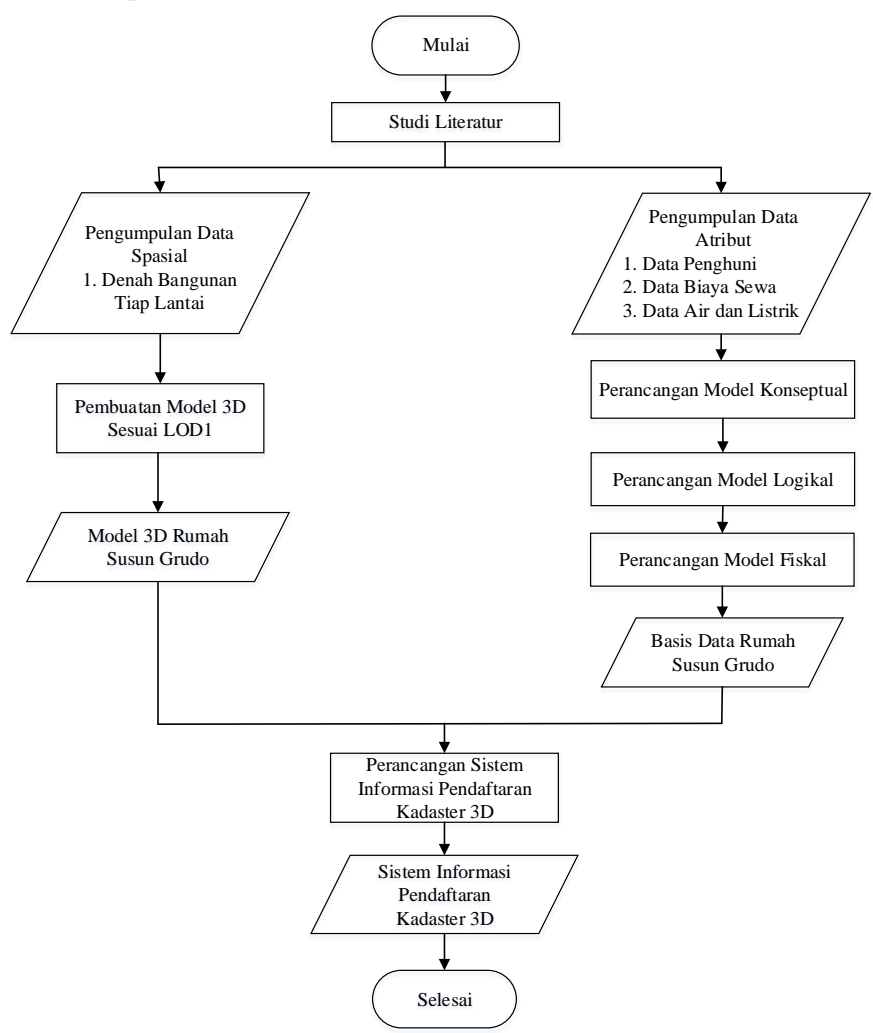

Gambar 2. Diagram Alir Penelitian

Tahapan penelitian dapat dilihat pada Gambar 2, dan untuk penjelasan diagram alir penelitian tersebut adalah sebagai berikut:

1. Studi Literatur

Tahap ini dilakukan untuk mencari sumber-sumber literatur yang mendukung dalam penelitian. Sumber literatur yang digunakan yaitu mengenai kadaster 3D, pemodelan 3 dimensi, basis data, dan bahasa pemrograman web (PHP, HTML, dan CSS).

\section{Pengumpulan Data}

Pada tahap ini dilakukan pengumpulan data-data yang digunakan dalam penelitian yang meliputi data spasial (denah bangunan tiap lantai) dan data atribut (data penghuni, data biaya sewa, serta data biaya air dan listrik) dari Rumah Susun Grudo yang didapatkan dari Dinas Pengelola Bangunan dan Tanah Kota Surabaya dan dari pengelola Rumah Susun Grudo, Surabaya.

3. Pembuatan Model 3D

Pada tahap ini dilakukan pemodelan 3D dari denah Rumah Susun Grudo menggunakan perangkat lunak SketchUp Make. Proses pembuatannya menggunakan tool push/pull yang kemudian ditarik atau didorong sesuai dengan ketinggian yang dibutuhkan. Model 3D yang dibuat disesuaikan dengan LOD1 (level of detail 1).

4. Pembuatan Basis Data

Pada tahap ini dilakukan perancangan / desain basis data yang meliputi:

a. Perancangan Konseptual 
Dalam penyusunan rancangan konseptual ini dilakukan identifikasi obyek-obyek yang akan dilibatkan dalam model data. Obyek-obyek tersebut dikelompokkan berdasarkan karakteristik yang ditentukan dengan atribut-atribut dan hubungan antar obyek. Pada penelitian ini, penyajian model konseptual menggunakan ER Diagram. Untuk model perancangan konseptual pada penelitian ini, dapat dilihat pada Gambar 3.

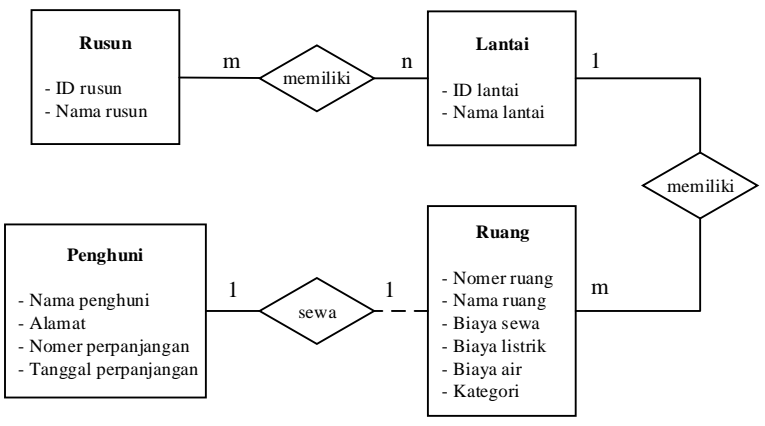

Gambar 3. Model Konseptual Basis Data

b. Perancangan Logikal

Pada tahap ini model data yang telah dibuat (hasil rancangan konseptual) ditransformasikan ke dalam model data yang sesuai dengan SMBD yang dipilih. Selain itu, pada tahap ini dilakukan penentuan atribut utama (primary key) dan atribut tamu (foreign key). Untuk model perancangan logikal pada penelitian ini, dapat dilihat pada Gambar 4.

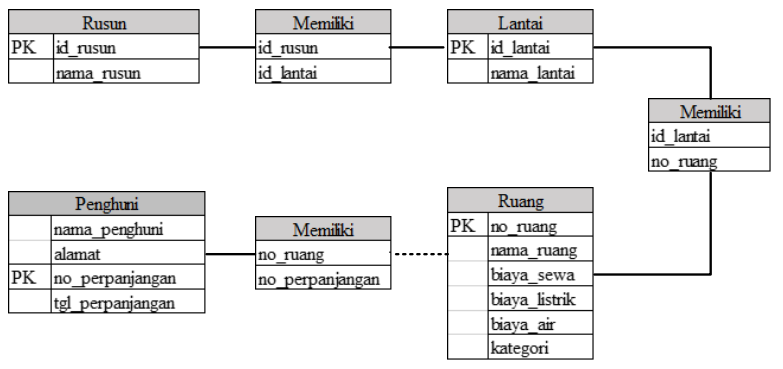

Gambar 4. Model Logikal Basis Data

\section{c. Perancangan Fiskal}

Pada tahap ini dilakukan pendefinisian basis data yang akan disimpan sesuai dengan SMBD yang digunakan yang meliputi struktur penyimpanan data, format data, dan jalur akses.

5. Perancangan Sistem Informasi Pendaftaran Kadaster 3D

Pada tahap ini dilakukan pembuatan sistem informasi pendaftaran kadaster 3D dengan menggunakan basis data 3D sebagai server data yang nantinya akan diakses oleh pengguna. Selain itu, juga dilakukan pembuatan tampilan visualisasi dari sistem informasi pendaftaran kadaster 3D secara online.

\section{HASIL DAN PEMBAHASAN}

\section{A. Pengolahan Data Spasial}

\section{Hasil Pembuatan Model 3D dengan SketchUp Make}

Hasil pembuatan model 3D dilakukan dengan perangkat lunak SketchUp Make, yang mana untuk menggambarkan model 3D dari Rumah Susun Grudo mulai dari lantai 1 sampai lantai 5. Di mana pada lantai 1 terdiri dari ruang pengelola, perpustakaan, kamar penghuni, mushola, tempat wudhu, ruang komersil, ruang panel, ruang pertemuan, dan tempat parkir. Sedangkan untuk lantai 2 sampai lantai 5 terdiri dari 24 satuan rumah susun (kamar penghuni) untuk setiap lantai. Untuk hasil model 3D dapat dilihat pada Gambar 5.

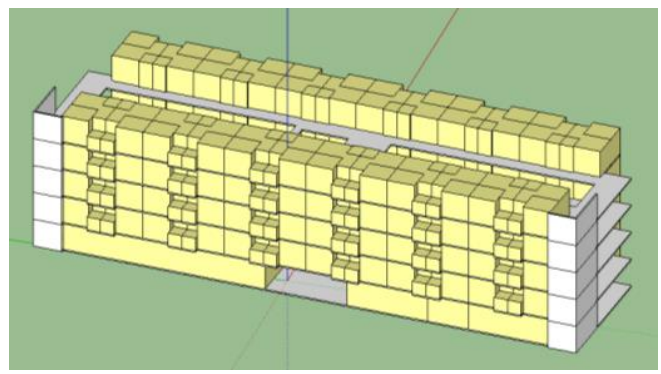

Gambar 5. Hasil Pembuatan Model 3D Keseluruhan Lantai

\section{B. Pengolahan Data Atribut}

Proses pengolahan data atribut dilakukan dengan perangkat lunak PostgreSQL (pgAdmin III). Berdasarkan data yang telah diperoleh dari Dinas Pengelola Bangunan dan Tanah (DPBT) Kota Surabaya, maka dalam penelitian ini terdapat 4 kategori tabel atribut. Keempat tabel atribut tersebut yaitu tabel rusun, tabel lantai, tabel ruang dan tabel penghuni.

Pada tabel rusun berisi informasi mengenai rumah susun yang ada di Surabaya, yakni terdapat 18 unit rumah susun. Pada tabel rusun ini terdiri dari 2 atribut tabel, yakni id_rusun dan nama_rusun. Tabel rusun dapat dilihat pada Gambar 6.

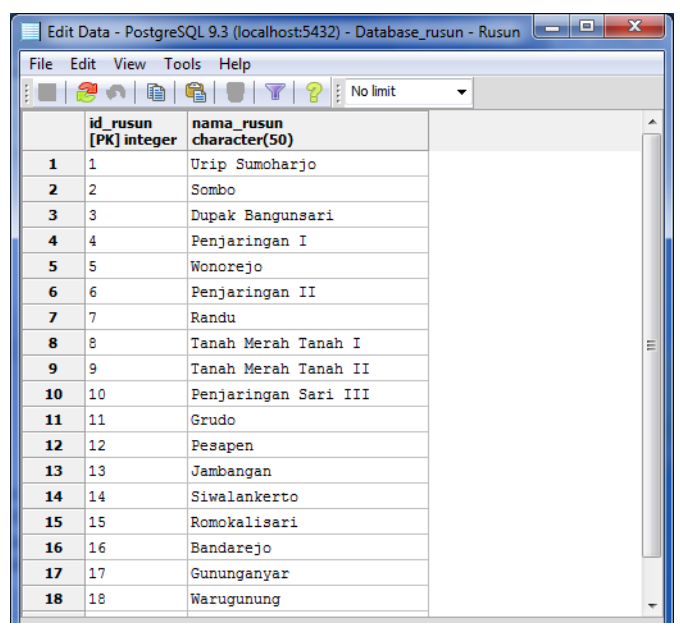

Gambar 6. Tabel Rusun

Pada tabel lantai berisi informasi mengenai lantai yang ada di Rumah Susun Grudo, yakni terdapat 5 lantai. Pada tabel lantai ini terdiri dari 3 atribut tabel, yakni id_lantai, nama_lantai dan id_rusun. Tabel lantai dapat dilihat pada Gambar 7. Sedangkan untuk tabel ruang berisi informasi mengenai ruang yang ada di Rumah Susun Grudo, yakni 
terdapat 108 ruang. Pada tabel ruang ini terdiri dari 7 atribut tabel, yakni no_ruang, nama_ruang, biaya sewa, biaya listrik, biaya air, kategori dan id_lantai. Tabel ruang dapat dilihat pada Gambar 8.

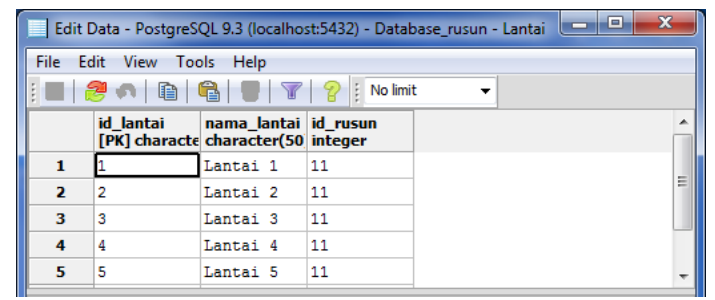

Gambar 7. Tabel Lantai

\begin{tabular}{|c|c|c|c|c|c|c|c|c|c|}
\hline D Edit & Data - PostgreS & SQL 9.3 (lo & localhost & ist:5432) - Datal & base_rusun - Rua & uang & & $-\square$ & 8 \\
\hline File & dit View To & ols Help & & & & & & & \\
\hline 미 & ชูㅁ & 盢 10 & $|\nabla|$ & | Q : No lim & $\checkmark$ & & & & \\
\hline & $\begin{array}{l}\begin{array}{l}\text { no_ruang } \\
{[\mathrm{PK}] \text { integer }}\end{array} \\
\end{array}$ & $\begin{array}{l}\text { nama_r } \\
\text { charact }\end{array}$ & $\begin{array}{l}\text { ruang } \\
\text { ter(50 }\end{array}$ & $\begin{array}{l}\text { biaya_sewa } \\
\text { integer }\end{array}$ & $\begin{array}{l}\text { biaya_listrik } \\
\text { integer }\end{array}$ & $\begin{array}{l}\text { biaya_air } \\
\text { integer }\end{array}$ & $\begin{array}{l}\text { kategori } \\
\text { character(50) }\end{array}$ & $\begin{array}{l}\text { id_lantai } \\
\text { character(10 }\end{array}$ & $A$ \\
\hline 1 & 101 & ] Ruang 1 & Lurah & & & & Ruang Bersama & 1 & \\
\hline 2 & 102 & Kamar & 102 & 80000 & & & Sarusun & 1 & \\
\hline 3 & 103 & Gudang & & & & & Ruang Bersama & 1 & \\
\hline 4 & 201 & Kamar & 201 & 72000 & 86881 & 15900 & Sarusun & 2 & \\
\hline 5 & 202 & Kamar 2 & 202 & 72000 & 73516 & 12000 & Sarusun & 2 & \\
\hline 6 & 203 & Kamar 2 & 203 & 72000 & 74050 & 12000 & Sarusun & 2 & \\
\hline 7 & 204 & Kamar 2 & 204 & 72000 & 81535 & 19800 & Sarusun & 2 & \\
\hline 8 & 205 & Kamar & 205 & 72000 & 86881 & 12000 & Sarusun & 2 & \\
\hline 9 & 206 & Kamar & 206 & 72000 & 127510 & 55000 & Sarusun & 2 & \\
\hline 10 & 207 & Kamar 2 & 207 & 72000 & 71377 & 15900 & Sarusun & 2 & \\
\hline 11 & 208 & Kamar 2 & 208 & 72000 & 29700 & 12000 & Sarusun & 2 & \\
\hline 12 & 209 & Kamar 2 & 209 & 72000 & 76189 & 18500 & Sarusun & 2 & \\
\hline 13 & 210 & Kamar & 210 & 72000 & 81000 & 31000 & Sarusun & 2 & \\
\hline 14 & 211 & Kamar & 211 & 72000 & 88484 & 23700 & Sarusun & 2 & \\
\hline 15 & 212 & Kamar 2 & 212 & 72000 & 57478 & 12000 & Sarusun & 2 & \\
\hline 16 & 213 & Kamar 2 & 213 & 72000 & 77258 & 12000 & Sarusun & 2 & \\
\hline 17 & 214 & Kamar 2 & 214 & 72000 & 68170 & 12000 & Sarusun & 2 & \\
\hline 18 & 215 & Kamar & 215 & 72000 & 62289 & 21100 & Sarusun & 2 & \\
\hline 19 & 216 & Kamar 2 & 216 & 72000 & 61220 & 12000 & Sarusun & 2 & \\
\hline 20 & 217 & Kamar 2 & 217 & 72000 & 93296 & 29000 & Sarusun & 2 & \\
\hline 21 & 218 & Kamar 2 & 218 & 72000 & 49993 & 12000 & Sarusun & 2 & \\
\hline 22 & 219 & Kamar 2 & 219 & 72000 & 79931 & 27000 & Sarusun & 2 & \\
\hline 23 & 220 & Kamar 2 & 220 & 72000 & 77258 & 12000 & Sarusun & 2 & \\
\hline 24 & 221 & Kamar & 221 & 72000 & 100780 & 12000 & Sarusun & 2 & \\
\hline
\end{tabular}

Gambar 8. Tabel Ruang

Pada tabel penghuni berisi informasi mengenai data penghuni rusun yang tinggal di Rumah Susun Grudo, yakni terdapat 97 penghuni. Pada tabel penghuni ini terdiri dari 5 atribut tabel, yakni nama_penghuni, alamat, no_ruang, no_perpanjangan, dan tgl_perpanjangan. Tabel penghuni dapat dilihat pada Gambar 9.

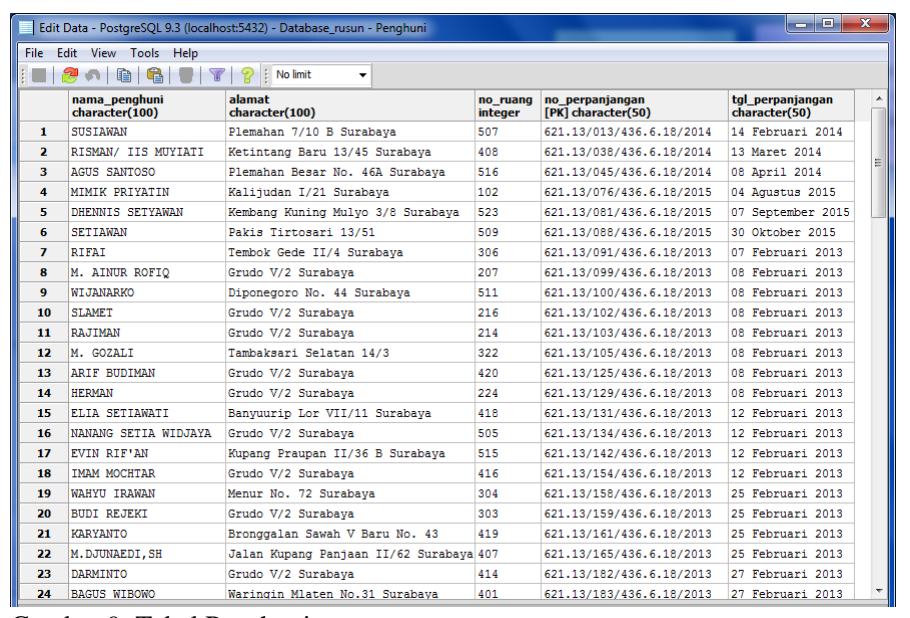

Gambar 9. Tabel Penghuni

\section{Pembuatan Sistem Informasi Pendaftaran Kadaster $3 D$}

Pembuatan sistem informasi pendaftaran kadaster 3D berbasis website ini dibuat dengan menggunakan perangkat lunak sublime dan menggunakan bahasa pemrograman $H T M L$, CSS dan PHP sehingga menghasilkan tampilan desain website seperti pada Gambar 10.

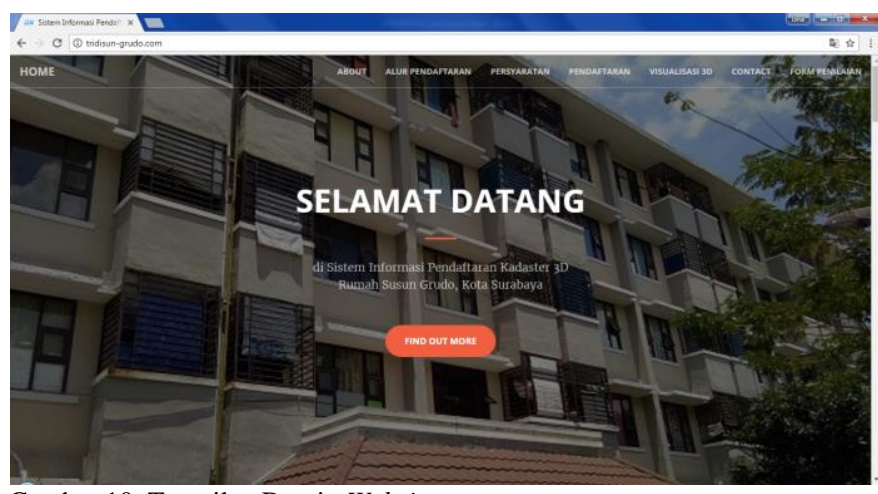

Gambar 10. Tampilan Desain Website

Pada sistem informasi pendaftaran kadaster 3D berbasis website yang telah dibuat, sistem website ini memiliki beberapa menu tampilan dan setiap menu tampilan ini memiliki fungsi masing-masing untuk mempermudah user dalam memahami sistem website yang dibuat.

\section{a. Halaman About}

Pada tampilan halaman About seperti yang ditunjukkan pada Gambar 11 berisi penjelasan singkat mengenai Rumah Susun Grudo Surabaya. Hal ini berfungsi sebagai informasi awal untuk pengunjung website.

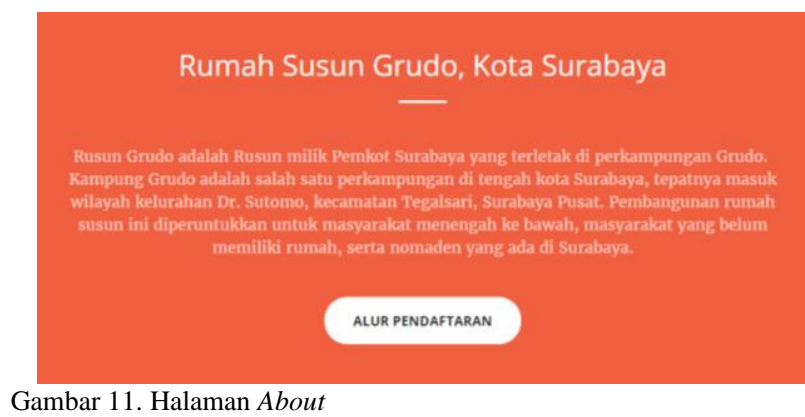

b. Halaman Alur Pendaftaran

Halaman Alur Pendaftaran seperti yang ditunjukkan pada Gambar 12 menampilkan informasi mengenai mekanisme alur pendaftaran untuk user yang ingin mendaftar sebagai calon penghuni Rumah Susun Grudo Surabaya. Pada halaman ini user dapat mengetahui langkah-langkah yang harus dilakukan mulai dari pendaftaran sampai mendapatkan Surat Izin Pemakaian Rumah Susun. 


\section{Alur Pendaftaran Sewa Rusun}

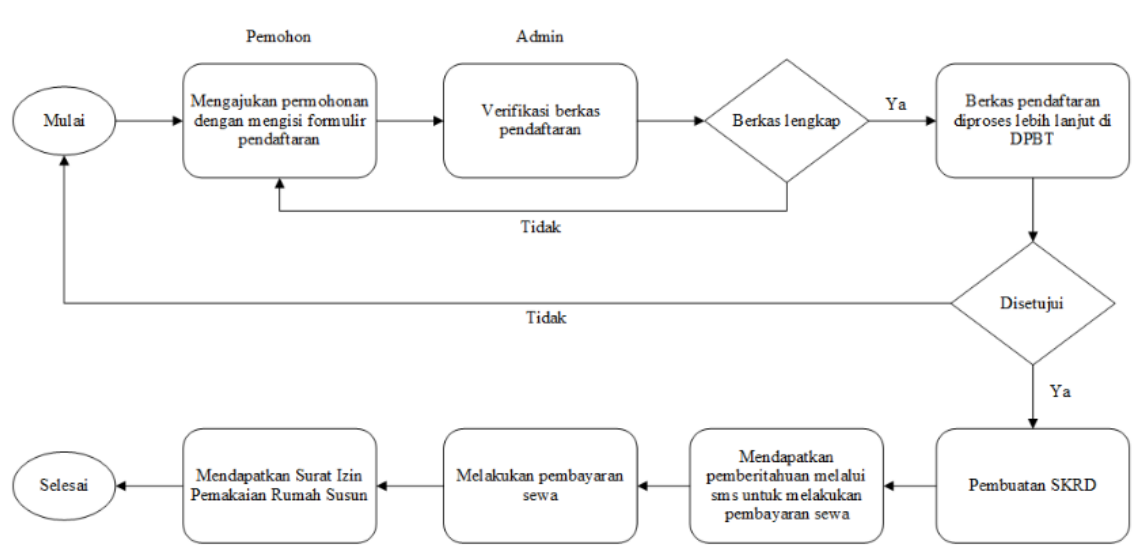

PERSYARATAN

Gambar 12. Halaman Alur Pendaftaran

\section{c. Halaman Persyaratan}

Halaman Persyaratan seperti yang ditunjukkan pada Gambar 13 menampilkan informasi mengenai syarat-syarat pendaftaran yang ditujukan untuk calon penghuni Rumah Susun Grudo Surabaya dan syarat-syarat perpanjangan tinggal yang ditunjukan untuk penghuni Rumah Susun Grudo Surabaya.

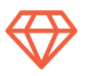

Syarat Pendaftaran

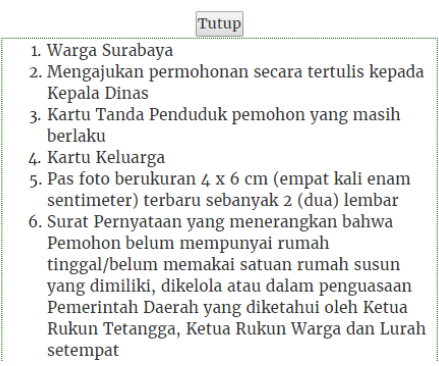

(a)

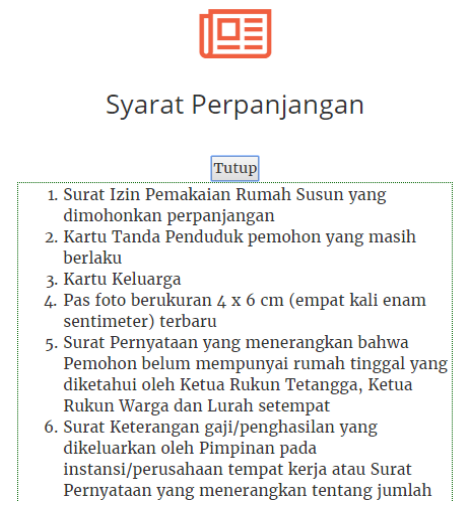

(b)

Gambar 13. Halaman Persyaratan (a) Syarat Pendaftaran (b) Syarat Perpanjangan

\section{d. Halaman Pendaftaran}

Formulir Pendaftaran Tinggal di Rumah Susun Grudo

\begin{tabular}{l} 
Nama \\
\hline \\
Alamat \\
\hline \\
No KTP \\
\hline \\
No HP/Telp \\
\hline \\
\hline Pekerjaan \\
\hline
\end{tabular}

Foto Scan KTP

Choose File No file chosen

Foto Scan KK

Choose File No file chosen

Pas Foto $4 \mathrm{x6}$

Choose File No file chosen

Surat Keterangan Tidak Memiliki Rumah Choose File No file chosen

Surat Keterangan Gaji Choose File No file chosen Surat Pernyataan Tinggal Choose File No file chosen

Submit

Gambar 14. Halaman Pendaftaran

Pada halaman Pendaftaran seperti yang ditunjukkan pada Gambar 14 menampilkan formulir pendaftaran yang harus diisi oleh calon penghuni Rumah Susun Grudo yang ingin melakukan pendaftaran secara online untuk tinggal di Rumah Susun Grudo Surabaya. Pada formulir pendaftaran ini, calon penghuni diharuskan untuk mengisi biodata diri serta mengunggah berkas-berkas yang sesuai dengan syarat-syarat yang disebutkan pada halaman persyaratan.

e. Halaman Visualisasi 3D

Pada halaman Visualisasi 3D seperti yang ditunjukkan pada Gambar 15 menampilkan visualisasi model 3D dari Rumah Susun Grudo dan informasi dari tiap ruang. Pada halaman visualisasi ini basis data dihubungkan dengan model 3D. 


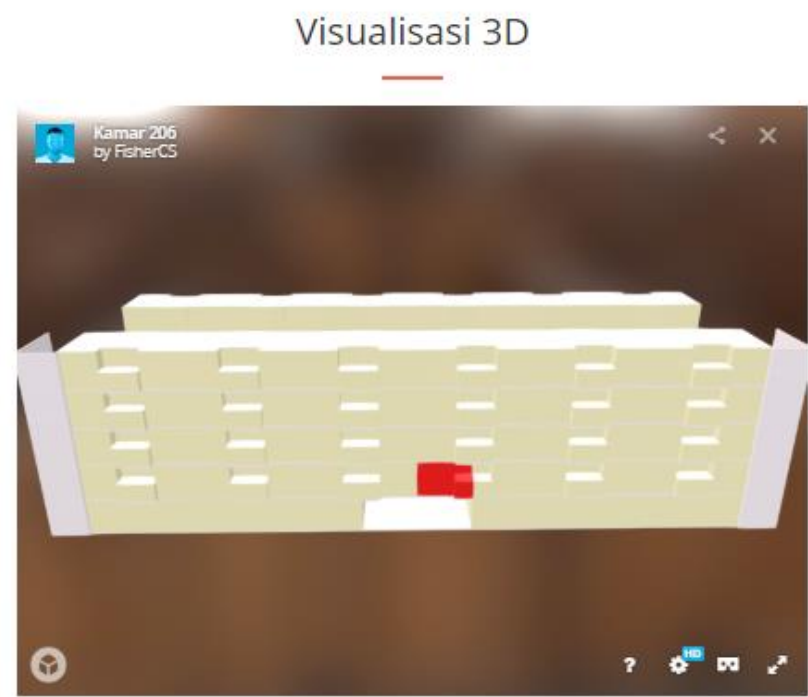

Pilih ruangan: Kamar 206 V

Informasi Penghuni

\begin{tabular}{l|l}
\hline Nama & ROCHANA HIDAYATI \\
\hline Alamat & Grudo V/2 Surabaya \\
\hline No Kamar & 206 \\
\hline No Perpanjangan & $621.13 / \mathrm{P}-005 / 436.7 .11 / 2017$ \\
\hline Tanggal Perpanjangan & 24 Januari 2017 \\
\hline
\end{tabular}

Gambar 15. Halaman Visualisasi 3D

f. Halaman Contact Person

\section{Contact Person}

Untuk informasi lebih lanjut, anda dapat menghubungi kontak yang ada di bawah ini
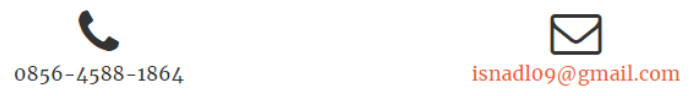

Gambar 16. Halaman Contact Person

Pada halaman Contact Person seperti yang ditunjukkan pada Gambar 16 menampilkan informasi kontak yang dapat dihubungi oleh user jika user ingin mendapatkan informasi lebih lanjut mengenai Sistem Informasi Pendaftaran Kadaster 3D ini.

\section{IV.KESIMPULAN}

Berdasarkan hasil penelitian yang telah dilakukan, maka didapatkan beberapa kesimpulan sebagai berikut:

a. Pembuatan model 3D dari Rumah Susun Grudo Surabaya dilakukan dengan menggunakan perangkat lunak pengolah gambar data spasial 3D yakni SketchUp Make. Tingkat ketelitian dari model 3D yang dibuat didasarkan pada LOD1 (Level Of Detail 1).

b. Pembuatan pemodelan sistem basis data kadaster 3D dilakukan dengan membuat perancangan model konseptual, model logikal, model fiskal, dan mengaplikasikannya pada perangkat lunak PostgreSQL.

c. Penelitian ini menghasilkan sebuah website Sistem Informasi Pendaftaran Kadaster 3D dengan domain www.tridisun-grudo.com, yang mana pada website model 3D dari Rumah Susun Grudo Surabaya berhasil divisualisasikan.

\section{UCAPAN TERIMA KASIH}

Penulis I.D.L. mengucapkan terima kasih kepada Dinas Pengelola Bangunan dan Tanah (DPBT) Kota Surabaya dan Rumah Susun Grudo, Surabaya yang telah membantu menyediakan data untuk penelitian.

\section{DAFTAR PUSTAKA}

[1] H. S. dan I. S. Rusmawar W, "Kadaster Masa Lalu dan Masa Mendatang di Indonesia," Inst. Teknol. Bandung, 2012.

[2] A. P. Parlindungan, "Kadaster," Inst. Teknol. Bandung, 2015.

[3] N. Cholis, "Kadaster Tiga Dimensi Untuk Kepentingan Pendaftaran Tanah Terhadap Hak Milik Atas Satuan Rumah Susun (HMASRS)," Institut Teknologi Bandung, 2008. 